\title{
EFEKTIVITAS PENAMBAHAN MEDIA GEOTEKSTIL PADA SARINGAN PASIR LAMBAT TERHADAP PENYISIHAN PARAMETER KEKERUHAN JUMLAH COLI DAN COD
}

\author{
Yustika Kusumawardani* dan Widi Astuti \\ Program Studi Teknik Lingkungan, Fakultas Teknik, Universitas Pandanaran Semarang \\ Jalan Banjarsari Barat No.1, Pedalangan Banyumanik Semarang
}

Submitted:03-01-2018; Revised: 29-03-2018; Accepted: 23-11-2018

\begin{abstract}
Slow sand filter processing is done by separating raw contaminant water which is passed slowly on sand. Fluctuating raw water quality resulted in the schmutzdecke layer not growing optimally. Therefore, it is needed media that help the performance of the sand filter. One of the media used is geotextile. The geotextile is useful as a medium to optimize the growth of microorganisms in the schmutzdecke layer. Geotextiles have similar surface structures such as sand filters as well as their pores. The purpose of this study was to determine the effectiveness of adding geotextiles in reducing turbidity parameters, number of coli and COD. This study used slow sand filter reactor with a continuous flow system of $0.3 \mathrm{m3} / \mathrm{m} 2 . j a m$ for 7 days. Based on the research, the addition of geotextile media is quite effective and can improve the performance of slow sand filter. Percentage of turbidity removal reached $94.27 \%$, coli $99.40 \%$ and COD $92.85 \%$. COD values tend to be dynamic as raw water conditions. Geotextiles is quite helpful in growing a layer of schmutzdecke because the structure resembles sand so as to increase the number of bacteria bed filters.
\end{abstract}

Keywords: Slow Sand Filter; Geotexile; Turbidity; Amount Coli; COD.

\begin{abstract}
ABSTRAK
Pengolahan saringan pasir lambat dilakukan dengan memisahkan air baku kontaminan yang dilewatkan perlahan pada media pasir. Kualitas air baku yang fluktuatif mengakibatkan lapisan schmutzdecke tidak tumbuh optimal. Oleh karena itu diperlukan media yang membantu kinerja saringan pasir tersebut. Salah satu media yang digunakan adalah geotekstil. Geotekstil bermanfaat sebagai media untuk mengoptimalkan pertumbuhan mikroorganisme pada lapisan schmutzdecke. Geotekstil memiliki struktur permukaan hampir sama seperti filter pasir demikian pula dengan pori-porinya.Tujuan penelitian ini untuk mengetahui efektivitas penambahan geotekstil dalam menurunkan parameter kekeruhan, jumlah coli dan COD. Penelitian dilakukan menggunakan reaktor saringan pasir lambat dengan sistem aliran kontinyu $0,3 \mathrm{~m}^{3} / \mathrm{m}^{2}$.jam selama 7 hari. Berdasarkan hasil penelitian, penambahan media geotekstil cukup efektif dan dapat meningkatkan kinerja saringan pasir lambat. Prosentase penyisihan kekeruhan mencapai 94,27\%, jumlah coli 99,40\% dan COD 92,85\%. Nilai COD cenderung dinamis seiring kondisi air baku. Geotekstil membantu menumbuhkan lapisan schmutzdecke karena strukturnya menyerupai pasir sehingga mampu meningkatkan jumlah bakteri bed filter.
\end{abstract}

Kata Kunci: Saringan Pasir Lambat; Geotekstil; Kekeruhan; Jumlah Coli; COD.

*Corresponding author: tika.yitka@gmail.com

Copyright@2019 THE AUTHOR(S). This article is distributed under a Creative Commons Attribution-Share Alike 4.0 International license. Jurnal Teknosains is published by the Graduate School of Universitas Gadjah Mada. 


\section{YUSTIKA KUSUMAWARDANI DAN WIDI ASTUTIO EFEKTIVITAS PENAMBAHAN MEDIA GEOTEKSTIL PADA SARINGAN PASIR LAMBAT TERHADAP PENYISIHAN ...}

\section{PENGANTAR}

Kebutuhan air minum di daerah perkotaan menjadi sangat penting, hal ini dibuktikan dengan semakin tingginya angka pertumbuhan penduduk dan tingkat kesadaran masyarakat pentingnya air bersih bagi kehidupan sehari-hari. Pada umumnya air baku yang menjadi sumber air minum diambil dari air permukaan (sungai). Kualitas air baku dari sungai ini tentunya tidak selalu stabil. Banyak faktor-faktor yang mempengaruhi kualitas air baku, di antaranya faktor fisik, kimia, dan biologis. Air baku yang ada pada saat ini tidak memenuhi syarat sebagai air baku untuk air minum karena umumnya mengandung limbah industri, rumah tangga, dan pertanian sehingga konsentrasi nitrogen, fosfat, kadar organik, deterjen, termasuk pestisida cukup tinggi.

Salah satu proses pengolahan air adalah pengolahan dengan saringan pasir lambat atau Slow Sand Filter (SSF). Saringan pasir lambat merupakan pengolahan air dengan cara memisahkan air baku dari kontaminan yang dilewatkan perlahan pada media pasir. Pengolahan ini memiliki prinsip kombinasi antara fisik (penyaringan dan sedimentasi) dan biologi (Huisman, 1974). Proses penyaringan pada saringan pasir lambat dilakukan melalui lapisan schmutzdecke yang terdiri dari lumpur alluvial, limbah organik, bakteri, alga, dan senyawa-senyawa biologi aktif di permukaan media filter pasir lambat dan tidak menggunakan bahan kimia (Campos, 2002). Kualitas air baku sungai yang bersifat fluktuatif mengakibatkan lapisan schmutzdecke yang berfungsi untuk menguraikan pencemar dalam air baku tidak dapat tumbuh dengan optimal sehingga proses filtrasi tidak maksimal (Dini R.P, 2013).

Keunggulan dari pengolahan saringan pasir lambat di antaranya adalah efektif mengolah air secara fisik, kimia serta biologi tanpa penambahan bahan kimia, proses pembuatan murah dan mudah, biaya operasional murah dan mudah serta lumpur yang tersisa dapat dimanfaatkan (Huisman dan Wood, 1974). Selain mempunyai keunggulan saringan pasir lambat juga mempunyai kelemahan. Kelemahan saringan pasir lambat antara lain rawan terjadi kebuntuan saat kekeruhan air baku tinggi, membutuhkan lahan yang cukup luas, pembentukan lapisan biofilm terganggu apabila kualitas air effluent tercemar senyawa toksik, serta tidak fleksibel di negara 4 musim karena akan membeku di musim dingin (Cheremisinoff, 2002). Semakin meningkatnya biomassa maka semakin mengurangi area kontak air baku dan biofilm sehingga dapat mengurangi transfer massa dan efisiensi pengolahan. Hal itulah yang menjadi salah satu penyebab terjadinya clogging.

Oleh karena itu, diperlukan media yang membantu kinerja saringan pasir dalam mengolah air. Salah satu media yang dapat digunakan untuk membantu proses saringan pasir lambat adalah media geotekstil. Geotekstil memiliki struktur permukaan yang hampir sama seperti struktur permukaan filter pasir demikian pula dengan pori-pori pada geotekstil sehingga dengan adanya kesamaan ini maka diharapkan bakteri bisa tumbuh menempel pada geotekstil tersebut. Penambahan geotekstil ini diharapkan dapat mempermudah proses pencucian saat mengalami clogging.

\section{Saringan Pasir Lambat}

Proses penyaringan pada saringan pasir lambat dilakukan dengan cara memisahkan air baku dari kandungan kontaminan berupa partikel tersuspensi dan koloid, serta bakteri, yang dilewatkan secara perlahan pada media pasir (Elliot $d k k$., 2008). Saringan pasir lambat efektif digunakan untuk pengolahan air minum sejak 200 tahun yang lalu (Weber dan Dick, 1999; serta Langenbach, et al., 2010). Media yang digunakan berupa pasir halus yang berfungsi sebagai filter dengan filtration rate yang rendah untuk menurunkan kekeruhan dengan proses fisik atau biologi (Ainsworth,1997).

Saringan pasir lambat merupakan salah satu proses pengolahan air yang efektif, murah, dan sederhana (Said dan Herlambang, 1997; Garibaldi, $d k k$., 2003). Saringan pasir lambat ini efektif karena dengan hanya menggunakan satu macam pengolahan mampu menghasilkan kualitas yang baik. Pada saringan pasir lambat terjadi pengurangan kekeruhan air sampai pada tingkat yang dapat ditoleransi untuk air 
bersih. Selain itu terjadi penurunan derajat warna dan konsentrasi bakteri yang cukup tinggi serta penurunan kandungan zat organik dan besi. Murah karena proses tersebut tidak memerlukan energi dan bahan kimia, serta pembangunannya tidak memerlukan biaya besar. Sederhana karena operasinya tidak memerlukan tenaga khusus yang terdidik dan terampil (Said dan Herlambang, 1997).

\section{Geotekstil}

Geotekstil adalah geosynthethic yang permeabel yang terdiri dari textile atau kain. Geotekstil terbuat dari polypropylene, polyester, polyethylene, polyamide(nylon), polyvinylidene chloride, dan fiberglas (Departments of The Army and The Air Force, 1995). Definisi lain adalah bahan polimer yang lulus air dapat berupa tenunan, rajutan, nir tenun (non woven) digunakan dalam pekerjaan geoteknik dan teknik sipil lainnya (SNI, 1996). Serat-serat geotekstil yang berupa polimer hidrofobik menyebabkan mikoorganisme dapat melekat pada permukaan yang tidak terlalu rata. Oleh karena itu, terbentuk matriks yang berupa lendir mengisi ruang-ruang antarserat geotekstil. Aliran air yang kontimu menyebabkan semakin tebalnya lapisan biofilm yang terbentuk sehingga menyebabkan poripori media tersumbat dan meningkatkan produk-produk dekomposisi.

Geotekstil yang terbuat dari PET ataupun PP bersifat hidrofobik sehingga partikel tersuspensi yang terbawa pada air baku dapat menjebak mikroorganisme dimana matrik yang terbentuk antarserat-serat geotextile dipengaruhi oleh variasi ukuran pori (Yaman, 2003).

\section{Metode}

Pada penelitian reaktor unit saringan pasir lambat dioperasikan dengan mengalirkan air outlet prasedimentasi ke bak penampung dengan menggunakan pompa, dari bak penampung air akan didistribusikan ke unit saringan pasir lambat secara gravitasi sehingga bak penampung harus lebih tinggi dari bak slow sand filter. Sistem aliran yang digunakan adalah sistem kontinu bahwa reaktor dioperasikan 24 jam/hari dengan $0,3 \mathrm{~m}^{3} / \mathrm{m}^{2}$.jam masing-masing variabel dilaksanakan selama 7 hari. Parameter yang dianalisis yaitu kekeruhan, COD, dan total coliform dengan penambahan media geotekstil.

Kekeruhan memiliki fungsi sebagai pembawa nutrisi untuk mikroorganisme yang dapat menyebabkan proses biologis terjadi di dalam air. Hal ini disebabkan karena akan ada nutrisi yang merupakan bahan organik untuk didegradasi oleh mikroorganisme sebagai bahan makanan. Oleh karena itu, nilai kekeruhan yang stabil dapat membantu keberlangsungan proses biologis dalam unit. Maka nilai kekeruhan sangat perlu diperhatikan pada saat pengoperasian unit slow sand filter.

COD adalah banyaknya oksigen yang di butuhkan untuk mengoksidasi bahanbahan organik secara kimia. Pengukuran COD dilakukan karena dalam bahan organik sering ditemukan bahan-bahan yang tidak dapat terurai secara biologis dan hanya dapat diuraikan secara kimiawi. Angka COD yang tinggi, mengindikasikan semakin besar tingkat pencemaran yang terjadi (Yudo, 2010).

Bakteri coliform merupakan salah satu mikroorganisme yang memiliki fase pertumbuhan seperti halnya mikroorganisme lainnya. Bakteri menjadi pendegradasi zat organik utama di dalam air. Pada proses ini karbon dioksida akan dilepaskan dan $\mathrm{pH}$ air akan mengalami penurunan. Secara bertahap makanan yang tersedia di dalam unit slow sand filter akan berkurang. Pada proses reduksi mikroorganisme, lapisan schmutzdecke memiliki peran yang cukup penting pada unit slow sand filter.

Air sampel yang diuji dalam penelitian ini yaitu air sampel sebelum masuk unit pengolahan saringan pasir lambat dan sampel air outlet setelah keluar dari reaktor unit saringan pasir lambat. Pengukuran parameter kekeruhan menggunakan metode Nephelometric. Pada metode ini unit kekeruhan yang digunakan adalah FTU (Formazin Turbidity Units) dan NTU (Nephelometric Turbidity Units). Pada nephelometri dan turbidimetri, sumber cahaya diproyeksikan melalui sampel cairan yang disimpan dalam wadah sampel transparan. Pengujian COD dilakukan dengan metode analisis titrimetri dan titrasi winkler. Sedangkan pengujian total bakteri pada inlet 
dan outlet dianalisis menggunakan metode TPC (Total Plate Count) yang didasarkan pada jumlah koloni yang tumbuh.

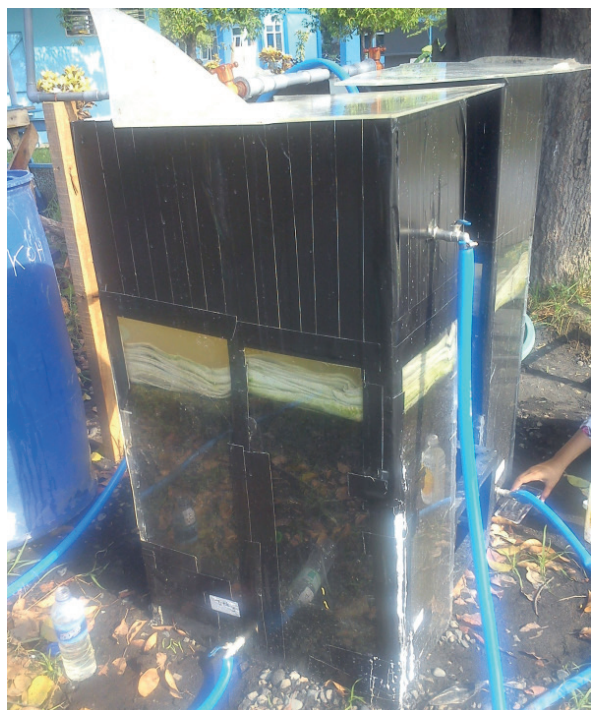

Gambar 1

Reaktor Saringan Pasir Lambat dengan penambahan Media Geotekstil

\section{HASIL DAN PEMBAHASAN}

Pada penelitian dilakukan pengolahan air menggunakan unit saringan pasir lambat dengan ketebalan media pasir yaitu $60 \mathrm{~cm}$, media kerikil $10 \mathrm{~cm}$, dan media geotekstil 4 $\mathrm{cm}$. Flow rate yang digunakan yaitu sebesar $0,3 \mathrm{~m}^{3} / \mathrm{m}^{2}$ jam. Media pasir yang digunakan merupakan jenis pasir kali yang memiliki diameter antara 0,15 mm-0,35 mm. Beberapa parameter yang diuji pada penelitian ini di antaranya adalah COD, total coli dan kekeruhan. Hal ini dilakukan untuk mengetahui seberapa besar efisiensi penyisihan parameterparameter tersebut, khususnya total coli oleh lapisan schmutzdecke yang berperan dalam unit saringan pasir lambat. Data yang didapatkan adalah 14 data sampel uji yang dapat dilihat pada Tabel 1 di bawah ini. Sedangkan untuk grafik penurunan parameter uji dapat dilihat pada Gambar 2.

Tabel 1.

Hasil Penelitian input dan output sampel air

\begin{tabular}{l|lllllll}
\hline \multirow{2}{*}{ Sampel Ke - } & \multicolumn{3}{c}{ Input } & \multicolumn{3}{c}{ Output } \\
\cline { 2 - 7 } 1 & Kekeruhan & Jumlah Coli & COD & Kekeruhan & Jumlah Coli & COD \\
\hline 2 & 19,5 & 17000 & 90,14 & 4,23 & 300 & 60,09 \\
3 & 5,25 & 4000 & 103,70 & 1,41 & 240 & 7,41 \\
4 & 3,06 & 2000 & 82,63 & 2,19 & 50 & 60,09 \\
5 & 14,5 & 50000 & 107,18 & 4,11 & 900 & 22,97 \\
6 & 10,6 & 26000 & 115,46 & 1,83 & 1600 & 98,97 \\
7 & 32,7 & 11000 & 67,37 & 4,9 & 1600 & 42,11 \\
8 & 33,4 & 17000 & 42,11 & 3,84 & 350 & 16,84 \\
9 & 23 & 4000 & 50,53 & 1,83 & 350 & 50,53 \\
10 & 40,7 & 8000 & 82,05 & 1,9 & 240 & 49,23 \\
11 & 36,2 & 50000 & 41,03 & 1,72 & 300 & 16,41 \\
12 & 13,5 & 8000 & 164,10 & 1,08 & 70 & 82,05 \\
13 & 16,6 & 14000 & 164,10 & 1,31 & 300 & 155,90 \\
14 & 21,3 & 13000 & 84,21 & 1,22 & 280 & 58,95 \\
\hline
\end{tabular}

Sumber: Hasil Analisis, 2013

Penurunan nilai kekeruhan cukup baik terjadi pada saat pengoperasian. Untuk mengetahui kualitas air hasil olahan, digunakan baku mutu persyaratan kualitas air minum Permenkes Nomor 492 Tahun 2010 sebagai acuan. Diketahui pada Permenkes Nomor 492 Tahun 2010 bahwa nilai kekeruhan maksimal pada air minum adalah 5 NTU. Berdasarkan nilai tersebut, kualitas air hasil olahan rata-rata pada variasi ini dinyatakan memenuhi syarat air minum. 


\section{Kekeruhan}
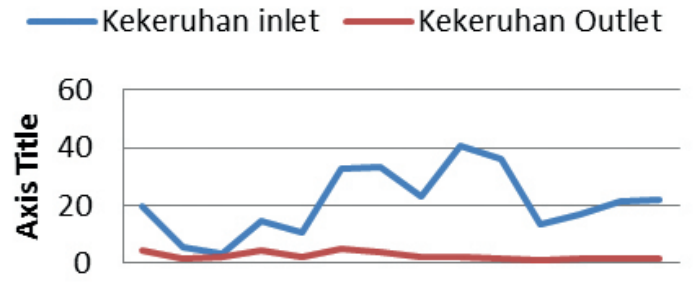

$\begin{array}{llllllllll}1 & 2 & 3 & 4 & 5 & 6 & 7 & 8 & 9 & 1011121314\end{array}$

\section{Jumlah Coli}

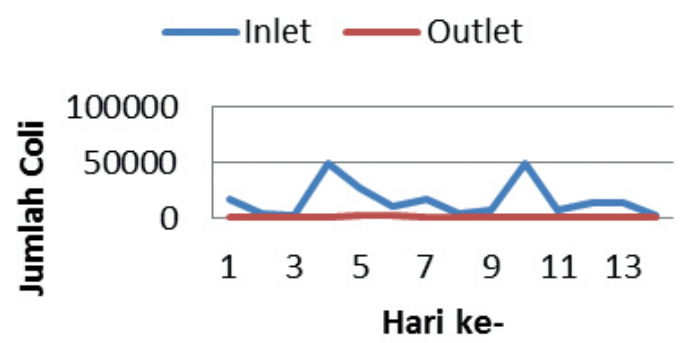

\section{COD}

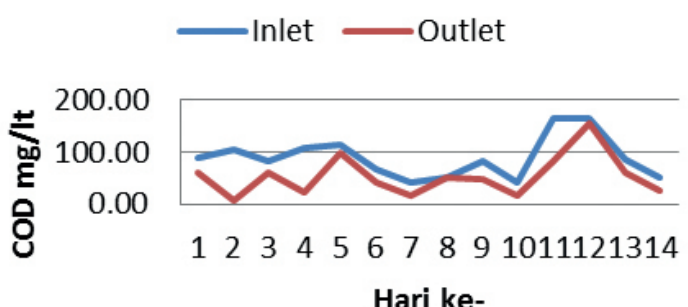

Gambar 2

Grafik Penurunan Parameter Uji (Kekeruhan, Jumlah Coli dan COD)

Berdasarkan Tabel 1 dan Gambar 2 Grafik Penurunan Parameter Uji di atas dapat dilihat bahwa terjadi penurunan total coli pada setiap titik pengambilan sampel. Untuk mengetahui kualitas air hasil olahan, digunakan baku mutu persyaratan kualitas air minum Permenkes Nomor 492 Tahun 2010 sebagai acuan. Diketahui pada Permenkes Nomor 492 Tahun 2010 bahwa nilai total coli maksimal pada air minum adalah 0 jumlah per $100 \mathrm{~mL}$ sampel. Berdasarkan nilai tersebut, kualitas air hasil olahan rata-rata pada variasi ini dinyatakan belum memenuhi syarat air minum. Oleh karena itu, diperlukan upaya untuk menghasilkan air yang dapat memenuhi syarat air minum. Upaya tersebut dapat dilakukan dengan pengolahan lebih lanjut seperti misalnya proses klorinasi. Selain itu jika tidak diinginkan proses lebih lanjut, dapat dilakukan dengan pemasakan air sebelum dikonsumsi.

Parameter COD berdasarkan hasil penelitian mengalami penurunan walupun tidak signifikan. Hal ini disebabkan tingginya beban yang diterima oleh reaktor sehingga banyak lumpur yang tertahan dipermukaan pasir, sebagai akibatnya reaktor cepat mengalami clogging. Setelah proses pencucian, membutuhkan waktu untuk menumbuhkan lapisan schmutzdecke dan proses penyisihan COD kembali berulang. Adanya proses adsorbsi selama melalui media penyaring sebagai akibat perbedaan muatan permukaan media dengan partikel tersuspensi dan koloidal di sekitarnya (Huisman dan Wood, 1974). Hasil presentase penyisihan parameter uji tersebut dapat dilihat pada Tabel 2 di bawah ini.

Tabel 2

Presentase Penyisihan Parameter Uji

\begin{tabular}{llll}
\hline & Kekeruhan & Jumlah Coli & \multicolumn{1}{c}{ COD } \\
\hline 1 & 78,31 & 98,24 & 33,34 \\
2 & 73,14 & 94,00 & 92,85 \\
3 & 28,43 & 97,50 & 27,28 \\
4 & 71,66 & 98,20 & 78,57 \\
5 & 82,74 & 93,85 & 14,28 \\
6 & 85,02 & 85,45 & 37,49 \\
7 & 88,50 & 97,94 & 60,01 \\
8 & 92,04 & 91,25 & 0,00 \\
9 & 95,33 & 97,00 & 40,00 \\
10 & 95,25 & 99,40 & 40,00 \\
11 & 92,00 & 99,13 & 50,00 \\
12 & 92,11 & 97,86 & 5,00 \\
13 & 94,27 & 97,85 & 30,00 \\
14 & 92,33 & 98,30 & 49,99 \\
\hline & 82,94 & 96,14 & 41,34 \\
\hline
\end{tabular}

Sumber: Hasil Analisis, 2013 


\section{YUSTIKA KUSUMAWARDANI DAN WIDI ASTUTIO EFEKTIVITAS PENAMBAHAN MEDIA GEOTEKSTIL PADA SARINGAN PASIR LAMBAT TERHADAP PENYISIHAN ...}

Berdasarkan presentase penyisihan parameter uji yang disajikan dalam tabel 2, rata-rata prosentase penyisihan kekeruhan adalah 82,94\% dan Jumlah Coli sebesar 96,14\%. Untuk parameter COD hasil input dan output mengalami kenaikan dan penurunan yang tidak menentu dengan prosentase penyisihan terbesar sebanyak $92,85 \%$ dan rata-rata prosentase penurunan berkisar $41,34 \%$. Nilai COD input cenderung bersifat dinamis dan terus berubah seiring dengan variasi kondisi dari air baku, sehingga mengakibatkan nilai penyisihan parameter COD juga berubah-ubah.

Pada unit reaktor ini terlihat bahwa jumlah bakteri banyak. Hal ini dikarenakan keberadaan geotekstil membantu peningkatan jumlah bakteri, dimana geotekstil ini memiliki struktur permukaan yang hampir sama seperti struktur permukaan filter pasir demikian pula dengan pori-porinya (Yaman, 2003), sehingga bakteri yang tersaring dapat tumbuh di atasnya. Selain itu penambahan geotekstil dapat memperluas bidang permukaan penempelan bakteri. Penurunan ini menunjukkan kondisi reaktor yang mulai mengalami proses clogging, sehingga pada lapisan schmutzdecke yang menebal tidak hanya terdapat biomassa, tetapi partikel-partikel koloid juga ikut tersaring. Selain itu keberadaan kompetitor bakteri seperti protozoa yang ikut tersaring dapat menghambat pertumbuhan dari bakteri pada lapisan schmutzdecke.

Geotekstil berfungsi membantu kinerja unit saringan pasir lambat (Rizki dkk, 2013). Serat-serat geotekstil yang berupa polimer hidrofobik menyebabkan mikoorganisme dapat melekat pada permukaan yang tidak terlalu rata. Oleh karena itu, terbentuk matriks yang berupa lendir mengisi ruang-ruang antar serat geotekstil. Aliran air yang kontinu menyebabkan semakin tebalnya lapisan biofilm yang terbentuk sehingga menyebabkan poripori media tersumbat dan meningkatkan produk-produk dekomposisi. Geotekstil yang terbuat dari PET ataupun PP bersifat hidrofobik sehingga partikel tersuspensi yang terbawa pada air baku dapat menjebak mikroorganisme di mana matrik yang terbentuk antarserat-serat geotextile dipengaruhi oleh variasi ukuran pori (Yaman, 2003). Keberadaan geotekstil cukup membantu dalam menumbuhkan lapisan schmutzdecke karena strukturnya yang menyerupai pasir, sehingga mampu meningkatkan jumlah bakteri pada bed filter.

Selanjutnya menurut Hamidah dan Trihadiningrum (2012) banyaknya jumlah mikroorganisme dan bakteri yang terdapat pada lapisan schmutzdecke juga mengurangi kekeruhan yang ada. Lapisan schmutzdecke mempunyai peran yang cukup besar dalam menyisihkan pencemar karena adanya matriks yang terbentuk dari hasil ekskresi mikroorganisme yang tumbuh dan berkembang pada media (Campos,2002). Kekeruhan air akan tertahan di media geotekstil dan juga lapisan schmutzdecke yang di dalamnya terdiri dari berbagai macam mikroorganisme, sehingga semakin banyak mikroorganisme yang ada pada lapisan schmutzdecke semakin tinggi pula efisiensi penyisihan kekeruhannya.

Selain itu semakin tebalnya lapisan biofilm yang terbentuk dari mikrorganisme, menyebabkan luas permukaan yang tersedia untuk transfer massa seperti substrat atau oksigen ke dalam biofilm semakin berkurang. Biofilm terdiri dari mikroorganisme dan partikulat yang saling berikatan dan membentuk matrik dari hasil ekstraseluler. Semakin meningkatnya biomassa, maka semakin mengurangi area kontak air baku dan biofilm sehingga dapat mengurangi transfer massa dan effisiensi pengolahan.

\section{SIMPULAN}

Berdasarkan hasil penelitian, penambahan media geotekstil dalam reaktor saringan pasir lambat cukup efektif, dan dapat meningkatkan kinerja saringan pasir lambat. Prosentase penyisihan kekeruhan terbesar mencapai 94,27\% dengan rata-rata penyisihan 82,94\%. Efektivitas penyisihan jumlah coli dapat mencapai $99,40 \%$ dengan rata-rata prosentase penyisihan $96,14 \%$. Penurunan parameter COD terbesar $92,85 \%$ dan rata-rata prosentase penurunan berkisar $41,34 \%$. Nilai COD input cenderung bersifat dinamis dan terus berubah seiring dengan variasi kondisi dari air baku, sehingga mengakibatkan nilai 
penyisihan parameter COD juga berubah-ubah. Keberadaan geotekstil cukup membantu dalam menumbuhkan lapisan schmutzdecke karena strukturnya yang menyerupai pasir, sehingga mampu meningkatkan jumlah bakteri pada bed filter.

\section{DAFTAR PUSTAKA}

APHA, AWWA. 1998. "Standard Methods For Examination of Water and Wastewater". Washington: APHA .

Ainsworth, R.G. (2007), "Water Treatment for Health Hazards", Journal Water and Environment, 4(5):489-493.

Ayuningtyas, Fitriani, N. dan Hadi, W. 2014. "Pengaruh Ketebalan Media Geotextile dan Arah Aliran Slow Sand Filter Rangkaian Seri untuk Menyisihkan P Total dan N Total." Jurnal Sains dan Seni Pomits, 3(1):2629, 10.12962/j23373539.v3i1.5383.

Bahgat, M., Dewedar, A., dan Zayed, A. (1999), "Sand-Filter Used for Wastewater Treatment: Build up and Distribution of Microorganisms", Journal of Water Research, 33 (8): 19491955.

Campos, L.C., Su, M.F.J., Graham, N.J.D., dan Smith, S.R. (2002), "Biomass Development in Slow Sand Filter", Journal of Water Research, 36: 45434511.

Cheremisinoff, Nicholas P. (2002), Handbook of Wasteater Treatment Technologies, Butterworth-Heinemann, USA.

Dini, R.P. 2013. "Penggunaan Unit Slow Sand Filter untuk Mengolah Air Kali Surabaya Menjadi Air Siap Minum". Tesis. Surabaya: Teknik Lingkungan FTSP-ITS Surabaya.

Faure, Y.H., Baudoin A., Pierson P., dan Ple O. 2006. "A Contribution For Predicting Geotextile Clogging During Filtration Of Suspended Solids". Geotextile and Geomembranes 24(1): 11-20.
Garibaldi, A., Minuto, A., Grasso, V., dan Gulino, M.L. 2003. "Application of Selected Antagonistic Strain Againts Phytophthora cryptogea on Gerbera in Closed Soilles System with Desinfection by Slow Sand Filtration", Journal of Crop Protection, 20:1053-1061.

Hamidah, N. L., dan Trihadiningrum, Y. 2012. "Studi Komunitas Bakteri pada Lapisan Schmutzdecke dalam Slow Sand Filter dengan Variasi berbagai Media Tumbuh." Tesis. Surabaya: Institut Teknologi Sepuluh Nopember.

Huisman, L. dan Wood, W.E. (1974), Slow Sand Filtration Handbook. World Health Organitation, Geneva, Swistzerland.

Hadi, Wahyono. 2012, "Perencanaan Bangunan Pengolahan Air Minum,. Surabaya: ITS Press.

Hendrayani, AA Dewi, Fitriani, N. and Hadi, W. "Pengaruh Ketebalan Media Geotekstil dan Arah Aliran Terhadap Penyisihan Kekeruhan dan Total Coli pada Slow Sand Filter Rangkaian Seri." Jurnal Sains dan Seni Pomits, 3(1):21-25.

Kusumawardani, Yustika. (2014). “Rekayasa Pola Perilaku Dinamik Kinerja Lapisan Schmutzdecke Pada Saringan Pasir Lambat". Institut Teknologi Sepuluh Nopember. Digilib.its.ac.id.

Logsdon, O.S., Kohne, R., Abel, S., dan LaBonde, S. (2002). "Slow Sand Filtration for Small Water System", Journal of Environmental Engineering Science, 1: 339-348.

Maharani, A. Ciptomulyono U., dan Santosa B. (2008). Pengembangan ModelOptimasi Manajemen Pengelolaan Kualitas Air Kali Surabaya dengan Interval Fuzzy Linier Programming (ILFP). Prosiding Seminar Nasional Manajemen Teknologi VIII Institut Teknologi Sepuluh Nopember. Surabaya. 
Peraturan Menteri Kesehatan Republik Indonesia Nomor 492/MENKES/ PER/IV/2010 tentang Persyaratan Kualitas Air Minum.

Rahmayanti, S. (2012), Analisis Penggunaan Downflow Slow Sand Filter Untuk Pengolahan Air Sumur untuk Menjadi Air Minum dengan Variasi Ketebalan Media dan Kecepatan Filtrasi. Tugas Akhir Jurusan Teknik Lingkungan ITS. Surabaya.

Rizki, M.H., Dini, R.P., dan Fitriani, N. (2013), "The Effectiveness of Geotextile on Slow Sand Filter in Removing Pollutant", The $4^{\text {th }}$ International Seminar Department of Environmental Engineering Department of Environmental Engineering, Institut Teknologi Sepuluh Nopember. Surabaya.

Said, N.I., dan Herlambang, A. 1997, "Pengolahan Air Bersih dengan Proses Saringan Pasir Lambat Up
Flow", Jurnal Teknologi Lingkungan, 6:672-789..

SNI. 1996. Istilah dan Definisi Geotekstil. Kemenperin. Diakses pada tanggal 20 Agustus 2013 jam 12.00 WIB. Dapat diakses di http://www. pustanbpkimi-kementrian.go.id/ files/SNI\%2008-4337-1996-pdf.

Yaman, C. (2003). “Geotextile as Biofilm Filter in Wastewater Treatment" Disertasi. United States: Drexel University.

Yudo, S. 2010, “Kondisi Kualitas Air Sungai Ciliwung di Wilayah DKI Jakarta ditinjau dari Parameter Organik, Amoniak, Fosfat, Deterjen dan Bakteri Coli". Jurnal Akuakultur Indonesia, 6:34-42. 